\title{
Microbial Properties of a Ferric Lixisol as Affected by Long Term Crop Management and Fertilization Regimes in Burkina Faso, West Africa
}

\author{
Noufou Ouandaogo', Mathias Bouinzemwendé Pouya', Dohan Mariam Soma', \\ Zacharia Gnankambary ${ }^{*}$, Delwendé Innocent Kiba ${ }^{1}$, Badiori Ouattara ${ }^{1}$, François Lompo ${ }^{1}$, \\ Hassan Bismark Nacro², Papaoba Michel Sedogo ${ }^{1}$ \\ ${ }^{1}$ Département Gestion des Ressources Naturelles/Systèmes de Production (GRN/SP), Institut de l'Environnement et de \\ Recherches Agricoles (INERA), Ouagadougou, Burkina Faso \\ ${ }^{2}$ Institut du Développement Rural (IDR), Université Nazi BONI, Bobo-Dioulasso, Burkina Faso \\ Email: ^gnank_zach@hotmail.com
}

How to cite this paper: Ouandaogo, N., Pouya, M.B., Soma, D.M., Gnankambary, Z., Kiba, D.I., Ouattara, B., Lompo, F., Nacro, H.B. and Sedogo, P.M. (2021) Microbial Properties of a Ferric Lixisol as Affected by Long Term Crop Management and Fertilization Regimes in Burkina Faso, West Africa. Open Journal of Soil Science, 11, 256-270. https://doi.org/10.4236/ojss.2021.114014

Received: March 17, 2021

Accepted: April 23, 2021

Published: April 26, 2021

Copyright (๑) 2021 by author(s) and Scientific Research Publishing Inc. This work is licensed under the Creative Commons Attribution International License (CC BY 4.0).

http://creativecommons.org/licenses/by/4.0/

(c) (i) Open Access

\begin{abstract}
We used an ongoing long-term field trial established since 1960 in Burkina Faso, to study the microbial properties of a Ferric Lixisol under various crop management and fertilization regimes. Microbial respiration rate, microbial biomass carbon $(\mathrm{MBC})$ and soil bacteria's number were assessed in soil samples taken at $0-20 \mathrm{~cm}$ depth. The crop management were continuous cropping of sorghum (Sorghum bicolor L.) (S/S) and rotation between sorghum and cowpea (Vigna unguiculata L.) (S/C), while the fertilization regimes were: 1) Control (te); 2) Low rate of mineral fertilizer (fm); 3) Low rate of mineral fertilizer + sorghum straw restitution (fmr); 4) Low rate of mineral fertilizer + low rate of manure (fmo); 5) High rate of mineral fertilizer (FM); and vii) High rate of mineral fertilizer + high rate of manure (FMO). The manure is applied every second year. The results indicate that sorghum/cowpea rotation significantly increase $\mathrm{MBC}$ and bacteria number as compared to continuous sorghum cropping. MBC ranged from 335.5 to $54.85 \mu \mathrm{g} \mathrm{C} \mathrm{g}^{-1}$ soil with $\mathrm{S} / \mathrm{S}$ and from 457.5 to $86.6 \mu \mathrm{g} \mathrm{C} \mathrm{g}^{-1}$ soil with S/C. Application of high level of manure and mineral fertilizer increase microbial respiration rate and MBC. The highest $\mathrm{MBC}$ was observed with FMO and the lowest with the control. In general, the metabolic quotient $\left(\mathrm{qCO}_{2}\right)$ was negatively impacted by the fertilization and cowpea rotation. For S/S rotation, $\mathrm{qCO}_{2}$ of the control was 1.5 to 2 times that of the treatments with low mineral fertilizer ( $\mathrm{fmr}, \mathrm{fmo}$ and $\mathrm{fm}$ ) and 3 times that of the high rate of fertilization (FM and FMO). With S/C ro-
\end{abstract}


tation, $\mathrm{qCO}_{2}$ of the control was 2 times of that fmr, FM and FMO and 0.8 times that of fmo and $\mathrm{fm}$. Soil bacteria in the fmr were 63.6 and 12.4 times the control in the S/S and S/C rotations, respectively. In sum, combined application of manure and mineral fertilizer with crop rotation is the best management practices to improve in sustainable way microbial activities in tropical soil.

\section{Keywords}

Microbial Respiration, Bacteria Quantification, Compost, Crop Rotation, Sorghum, Cowpea

\section{Introduction}

The integration of legumes in the cropping systems is known to have positive effects on subsequent cereal yield. This positive effect was attributed to the enhanced soil health resulting from the increase of available nitrogen through biological nitrogen fixation, maintenance of soil structure, increase in soil carbon and physical properties, disruption of pest cycles, and weed suppression [1] [2] [3] originating from the activities of soil microorganisms [4].

In Sub Sahara Africa including Burkina Faso, farmers often produce sorghum [Sorghum bicolor L.] in bare soil with little or without fertilization for their own consumption. These cropping systems often include cotton in the rotation as a cash crop in the cotton cropping areas and more generally legume crops like cowpea and groundnut. In such systems, soil fertility management relies on the application of little mineral fertilizers with or without organic amendments mainly composts, crop residues, and farmyards manures [5]. Conflicting results on the effects of mineral fertilizer and organic amendments application on soil microbial activities have been reported. For instance, an increase of soil microbial respiration and enzymatic activities following mineral fertilizer and manure application has been reported [6] [7] [8] and attributed to higher soil carbon, higher nutrient availability, crop roots and, additional microbes from manure. On the other hand, long-term application of mineral fertilizer results in the decrease of microbial biomass probably due to soil acidification and decrease of soil carbon content due to increased mineralization as reported by Geisseler, et al. [7].

Soil microbial respiration rate, biomass, metabolic quotient $\left(\mathrm{qCO}_{2}\right)$, or enzymatic activity have been used as potential indicators for change in soil quality because they are sensitive to soil management [9]. Geisseler, et al. [7] analyze the responses of soil microorganisms to mineral fertilizer using 107 datasets from 64 long-term fertilization trials in cropping systems. Only 3 datasets originate from Africa implying that little evidence is available on soil biological properties under long-term application on mineral fertilizer and organic amendments and crop rotation in tropical soils.

In this study, we investigate the potential of some entry points of integrated 
soil fertility management on soil biological properties. Our objectives were to assess the long-term effects of 1) crop rotation (cowpea-sorghum) and 2) application of mineral fertilizer with and without organic matter on soil microbial properties. This was done by measuring soil microbial respiration rates, microbial biomass, and quantification, and assessing the microbial metabolic quotient in soil samples from long-term experiments. We hypothesized that 1) sorghum-cowpea rotation will increase soil microbial biomass compared to continuous sorghum cropping and 2) combined application of mineral fertilizer and manure will result in greater microbial biomass and activity than the only application of mineral fertilizer.

\section{Material and Methods}

\subsection{Site Description}

The experiment was conducted in 2012 at Saria agricultural research station $\left(12^{\circ} 16^{\prime} \mathrm{N}, 2^{\circ} 9^{\prime} \mathrm{W}\right)$ in Burkina Faso. The climate was north-Sudanian with monomodal rainfall and unevenly distributed (Figure 1 ). The total rainfall during the experiment year was $856 \mathrm{~mm}$; mean daily temperatures vary from $30^{\circ} \mathrm{C}$ during the rainy season to $45^{\circ} \mathrm{C}$ in April and May. The soil type was Ferric Lixisol. The vegetation type was an open woody savannah and the main species were Parkia biglobosa, Vitellaria paradoxa, and Tamarindus indica. The herbaceous component was dominated by Pennisetum pedicellatum, Andropogon sp., Loudetia togoensis, and Schoenfeldia gracilis.

\subsection{Experimental Layout}

The long-term trial established in 1960 at the research station of Saria (Burkina Faso), which is still ongoing, was used to evaluate the soil microbial properties under different crop management and fertilization regimes. The experiment design is a split-plot with six blocs (replicates), six (06) levels of fertilization treatments and three levels in the rotation treatments.)

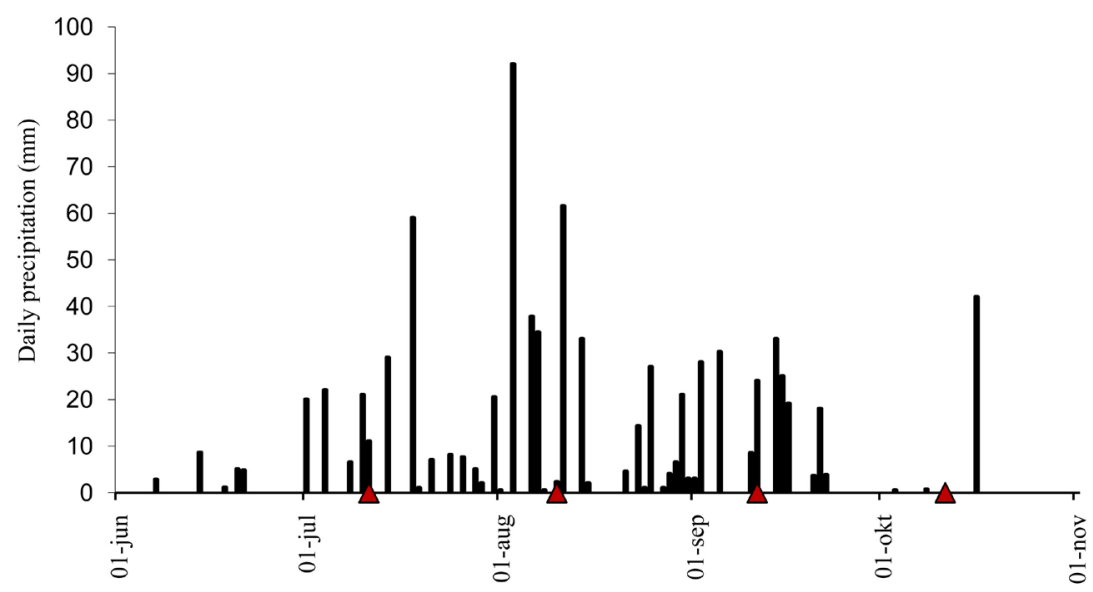

Figure 1. Daily precipitation in 2012 at Saria research station in Burkina Faso. The red triangles indicate the four soil sampling dates. 
The Main fertilization treatments are:

- Control, without any fertilizer (te);

- Low rate of mineral fertilizer $\left(100 \mathrm{~kg} \cdot \mathrm{ha}^{-1}\right.$ of $\mathrm{NPK}+50 \mathrm{~kg} \cdot \mathrm{ha} \mathrm{H}^{-1}$ of urea $)+$ sorghum straw restitution (fmr);

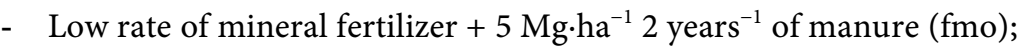

- Low rate of mineral fertilizer (fm);

- High rate of mineral fertilizer $\left(100 \mathrm{~kg} \cdot \mathrm{ha}^{-1}\right.$ of NPK $+100 \mathrm{~kg} \cdot \mathrm{ha} \mathrm{a}^{-1}$ of urea +50 $\mathrm{kg} \cdot \mathrm{ha}^{-1}$ of $\left.\mathrm{KCl}\right)+40 \mathrm{Mg} \cdot \mathrm{ha}^{-1} 2$ years $^{-1}$ of manure (FMO);

- High rate of mineral fertilizer (FM).

The rotation treatments are:

- Sorghum/sorghum (Sorghum bicolor L.);

- sorghum/cotton (Gossipium hirsutum);

- sorghum/cowpea (Vigna unguiculate L.).

In our study, we have considered two rotations: sorghum/sorghum (S/S) and sorghum/cowpea (S/C). The study was conducted in 2012 where the sorghum cultivar ICSV 1049 was cropped in all the rotation plots. The dimension of the individual plot was $10.0 \mathrm{~m}$ by $8.40 \mathrm{~m}$. Mineral fertilizers were NPK $14.23 .14+6 \mathrm{~S}$ $+1 \mathrm{~B}$, urea $(46 \% \mathrm{~N})$ and $\mathrm{KCl}\left(46 \% \mathrm{~K}_{2} \mathrm{O}\right)$. One-third of the urea was applied three weeks after sowing together with the total doses of $\mathrm{NPK}$ and $\mathrm{KCl}$, and the remaining two-thirds at the time of the flowering stage.

Organic amendments (manure: $\mathrm{N}=0.11 \mathrm{~g} \cdot \mathrm{kg}^{-1}, \mathrm{C}=0.20 \mathrm{~g} \cdot \mathrm{kg}^{-1}$; and sorghum straw: $\mathrm{N}=0.05 \mathrm{~g} \cdot \mathrm{kg}^{-1}, \mathrm{C}=0.39 \mathrm{~g} \cdot \mathrm{kg}^{-1}$ ) were applied on the soil surface on the plots that were concerned and then incorporated into the soil by ploughing at the depth of $15-20 \mathrm{~cm}$ few days before sowing. Selected soil chemical properties of the trial in 2012 before sowing are presented in Table 1 (Ouandaogo N., unpublished data).

Table 1. Selected soil chemical characteristics before ploughing following crops rotation and fertilizer application at the Saria long-term experiment in Burkina Faso, West Africa; $(n=6)$. Treatments with the same letter within columns are not statistically different at the $5 \%$ level.

\begin{tabular}{ccccccc}
\hline Rotation & Treatment & $\begin{array}{c}\text { Total-C } \\
\left(\mathrm{g} \cdot \mathrm{kg}^{-1}\right)\end{array}$ & $\begin{array}{c}\text { Total-N } \\
\left(\mathrm{g} \cdot \mathrm{kg}^{-1}\right)\end{array}$ & $\begin{array}{c}\text { Exchangeable } \\
\mathrm{Al}^{3+}\left(\mathrm{cmol}^{\circ} \mathrm{kg}^{-1}\right)\end{array}$ & $\begin{array}{c}\text { P-Bray } \\
\left(\mathrm{mg} \cdot \mathrm{kg}^{-1}\right)\end{array}$ & $\mathrm{pH}-\mathrm{H}_{2} \mathrm{O}$ \\
\hline \multirow{3}{*}{ Sorghum-Sorghum } & te & $1.98 \mathrm{a}$ & $0.18 \mathrm{a}$ & $0.00 \mathrm{a}$ & $4.60 \mathrm{a}$ & $5.4 \mathrm{c}$ \\
& $\mathrm{fmr}$ & $2.16 \mathrm{a}$ & $0.19 \mathrm{a}$ & $0.11 \mathrm{~b}$ & $18.90 \mathrm{~b}$ & $4.0 \mathrm{a}$ \\
& $\mathrm{fmo}$ & $3.31 \mathrm{c}$ & $0.37 \mathrm{c}$ & $0.00 \mathrm{a}$ & $33.80 \mathrm{~d}$ & $4.6 \mathrm{~b}$ \\
& $\mathrm{fm}$ & $2.32 \mathrm{a}$ & $0.28 \mathrm{~b}$ & $0.25 \mathrm{c}$ & $26.00 \mathrm{c}$ & $4.0 \mathrm{a}$ \\
& $\mathrm{FMO}$ & $6.92 \mathrm{~d}$ & $0.61 \mathrm{~d}$ & $0.00 \mathrm{a}$ & $48.30 \mathrm{e}$ & $5.9 \mathrm{~d}$ \\
& $\mathrm{FM}$ & $2.42 \mathrm{ab}$ & $0.21 \mathrm{a}$ & $0.45 \mathrm{~d}$ & $20.00 \mathrm{~b}$ & $3.9 \mathrm{a}$ \\
\hline & $\mathrm{te}$ & $1.91 \mathrm{a}$ & $0.19 \mathrm{a}$ & $0.00 \mathrm{a}$ & $4.40 \mathrm{a}$ & $4.8 \mathrm{c}$ \\
& $\mathrm{fmr}$ & $2.25 \mathrm{a}$ & $0.20 \mathrm{a}$ & $0.15 \mathrm{~b}$ & $11.60 \mathrm{~b}$ & $4.0 \mathrm{a}$ \\
& $\mathrm{fmo}$ & $3.81 \mathrm{c}$ & $0.31 \mathrm{~b}$ & $0.00 \mathrm{a}$ & $22.00 \mathrm{~d}$ & $4.4 \mathrm{~b}$ \\
& $\mathrm{fm}$ & $2.60 \mathrm{~b}$ & $0.25 \mathrm{a}$ & $0.20 \mathrm{c}$ & $17.60 \mathrm{c}$ & $4.0 \mathrm{a}$ \\
& $\mathrm{FMO}$ & $7.80 \mathrm{~d}$ & $0.68 \mathrm{c}$ & $0.00 \mathrm{a}$ & $35.10 \mathrm{e}$ & $5.9 \mathrm{~d}$ \\
& $\mathrm{FM}$ & $2.87 \mathrm{~b}$ & $0.22 \mathrm{a}$ & $0.26 \mathrm{c}$ & $16.30 \mathrm{c}$ & $3.9 \mathrm{a}$ \\
\hline
\end{tabular}


The results in Table 1 indicate that whatever the crop rotation system, soil total-C, total-N and P-Bray were highest with the application of manure (FMO and fmo) and lowest with the control. In the S/S rotation, soil total-C and total-N and P-Bray, varied between $6.92 \mathrm{~g} \cdot \mathrm{kg}^{-1}$ and $1.98 \mathrm{~g} \cdot \mathrm{kg}^{-1} ; 0.61 \mathrm{~g} \cdot \mathrm{kg}^{-1}$ and 0.18 $\mathrm{g} \cdot \mathrm{kg}^{-1} ; 48.30 \mathrm{mg} \cdot \mathrm{kg}^{-1}$ and $4.60 \mathrm{mg} \cdot \mathrm{kg}^{-1}$ respectively. In the S/C rotation, these parameters varied between $7.8 \mathrm{~g} \cdot \mathrm{kg}^{-1}$ and $1.91 \mathrm{~g} \cdot \mathrm{kg}^{-1} ; 0.68 \mathrm{~g} \cdot \mathrm{kg}^{-1}$ and $0.19 \mathrm{~g} \cdot \mathrm{kg}^{-1}$; $35.10 \mathrm{mg} \cdot \mathrm{kg}^{-1}$ and $4.40 \mathrm{mg} \cdot \mathrm{kg}^{-1}$ respectively. The soil $\mathrm{pH}-\mathrm{H}_{2} \mathrm{O}$ was highest (5.9) in the FMO treatments and lowest (4.0) with the low rate of exclusive low mineral fertilization $(\mathrm{fm})$, crop residues restitution $(\mathrm{fmr})$ and the exclusive high mineral fertilization (FM). Exchangeable Al was undetectable $\left(<0 \mathrm{cmol} \cdot \mathrm{kg}^{-1}\right)$ in the control and the manure application (fmo and FMO) and highest in the FM treatments with $0.45 \mathrm{cmol} \cdot \mathrm{kg}^{-1}$ and $0.26 \mathrm{cmol} \cdot \mathrm{kg}^{-1}$ in the $\mathrm{S} / \mathrm{S}$ and $\mathrm{S} / \mathrm{C}$ rotation respectively.

\subsection{Soil Sampling and Analysis}

Composite auger samples of three subsamples at $0-20 \mathrm{~cm}$ were taken in 2012 from each plot on four occasions: 1) before ploughing (0DAS); 2) at 30 days after sowing (30DAS), 3) at 60 days after sowing (60DAS) and 4) at 90 days after sowing (90DAS). Soil samples were dried and sieved through a $2 \mathrm{~mm}$ mesh for biological properties determination which included 1) soil microbial respiration rate; 2) soil microbial biomass carbon; 3) microbial metabolic quotient; and 4) soil bacteria's quantification.

\subsubsection{Soil Microbial Respiration Rate}

Heterotrophic microbial respiration was measured using an incubation-alkaline absorption method [10]. Briefly, $20 \mathrm{~g}$ of dry soil were weighed, and the water content of the soil was adjusted to $60 \%$ water holding capacity and placed in a 1 $\mathrm{L}$ vessel. A beaker containing $20 \mathrm{ml}$ of $0.1 \mathrm{~mol} \cdot \mathrm{l}^{-1} \mathrm{NaOH}$ was placed on the moist soil and the vessels were incubated at $30^{\circ} \mathrm{C}$.

Total $\mathrm{CO}_{2}-\mathrm{C}$ in the $\mathrm{NaOH}$ traps was determined by titrating the excess $\mathrm{NaOH}$ with $0.1 \mathrm{~mol} \cdot \mathrm{l}^{-1} \mathrm{HCl}$ after precipitation of carbonates with $3 \% \mathrm{BaCl}_{2}$ in the presence of la phenolphthalein as color indicator. $\mathrm{CO}_{2}$ production was measured daily for the first 7 days and then every 2 days for 14 days more.

Microbial respiration was estimated as $\mu \mathrm{g} C-\mathrm{CO}_{2} \mathrm{~kg}^{-1}$ soil according to Equation (1).

$$
\mathrm{C}-\mathrm{CO}_{2}\left(\mu \mathrm{g} \cdot \mathrm{kg}^{-1}\right)=\left(V_{\text {blank }}-V_{\text {sample }}\right) \times 2.2 / W
$$

where: $V_{\text {blank }}$ is the number of $\mathrm{ml}$ of $0.1 \mathrm{~mol} \cdot \mathrm{l}^{-1} \mathrm{HCl}$ used to titrate the $\mathrm{NaOH}$ in the control vessel; $V_{\text {sample }}$ is the number of $\mathrm{ml}$ of $0.1 \mathrm{~mol} \cdot \mathrm{l}^{-1} \mathrm{HCl}$ used to titrate the $\mathrm{NaOH}$ in the sample vessel.

The factor 2.2 is related to the fact that $1 \mathrm{ml}$ of $0.1 \mathrm{~mol} \cdot \mathrm{l}^{-1} \mathrm{HCl}$ corresponds to $2.2 \mathrm{~g} \mathrm{C}^{-} \mathrm{CO}_{2}[11] ; W$ is the weight of sample in $\mathrm{kg}$.

Then, soil microbial respiration rate expressed as $\mu \mathrm{g} \mathrm{C}-\mathrm{CO}_{2} \mathrm{~kg}^{-1} \cdot \mathrm{d}^{-1}$ was calculated by averaging total $\mathrm{C}-\mathrm{CO}_{2}$ production during the 21 days of incubation. 


\subsubsection{Soil Microbial Biomass Carbon}

Microbial biomass $\mathrm{C}$ (MBC) was determined according to the chloroform fumigation method as described by Jenkinson and Powlson [12]. In this method, the microbial cells in soil are killed by fumigation with alcohol-free chloroform, and then subjected to mineralization for 14 days at a constant temperature $\left(30^{\circ} \mathrm{C}\right)$. Controls consist of identically incubated but non-chloroformed soil samples. The amount of MBC is calculated from the difference between the $\mathrm{CO}_{2}-\mathrm{C}$ evolved from chloroform-fumigated and non-fumigated samples (Equation (2)):

$$
\mathrm{MBC}=\left[\mathrm{F}_{(0-7)}-\mathrm{nF}_{(7-14)}\right] / \mathrm{kc}
$$

where: $\mathrm{F}_{(0-7)}$ representing the total $\mathrm{C}-\mathrm{CO}_{2}$ production between the 0 and 7 days of incubation of the fumigated soil, $\mathrm{nF}_{(7-14)}$ representing the total $\mathrm{C}-\mathrm{CO}_{2}$ production between the 7 and 14 days of incubation of the non-fumigated soil. $\mathrm{kc}$ is the factor representing the proportion of $\mathrm{C}$ mineralized during the incubation. We used the factor 0.41 according to [13].

\subsubsection{Microbial Metabolic Quotient}

The microbial metabolic quotient $\left(\mathrm{qCO}_{2}\right)$ was calculated as the amount of $\mathrm{CO}_{2}-\mathrm{C}$ produced per unit of microbial biomass $\mathrm{C}$.

\subsubsection{Soil Bacteria's Quantification}

The bacteria's density was evaluated using the suspension-dilution method. Sequential dilution at a ratio of 1-to-10 was realized on an initial solution form with $5 \mathrm{~g}$ of soil in $45 \mathrm{ml}$ of sterile water. An aliquot of $100 \mu \mathrm{l}$ of appropriate dilution $10^{-3}, 10^{-4}$ and $10^{-5}$ were spread using balls in the YPGA1/2 (Yeast-Peptone Glucose Agar) medium in Petri dishes. For each of the dilution level, three Petri dishes were prepared and incubated at $25^{\circ} \mathrm{C}$. Bacteria colonies were counted after 3 and 5 days.

\subsection{Statistical Analysis}

The effect of crop rotation and fertilization on soil chemical and biological properties was subjected to analysis of variance (ANOVA). We used General Linear Model (GLM) univariate implemented in Minitab (V. 14) statistical software for Windows (Minitab Inc.). Means that showed differences at $\mathrm{p}<0.05$ were compared using Tukey's pair-wise tests.

\section{Results}

\subsection{Soil Microbial Respiration Rate}

Soil microbial respiration rate of soil samples before (0DAS) and after (30, 60 and 90 DAS) sowing and applications of manure and mineral fertilizers are shown in Figure 2.

In the $S / S$ rotation, the respiration rate was highest at $0 \mathrm{DAS}$ and then decreased and remain constant at 30DAS 60DASand 90DAS except for treatment with manure application (fmo and FMO) where it increased at 90DAS. The highest respiration rates were observed with FMO and varied between $46 \pm 0.9$ and 


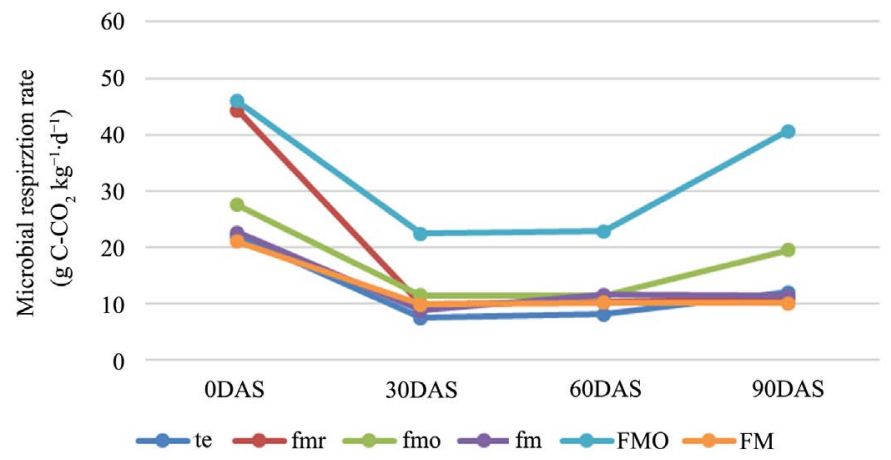

(a)

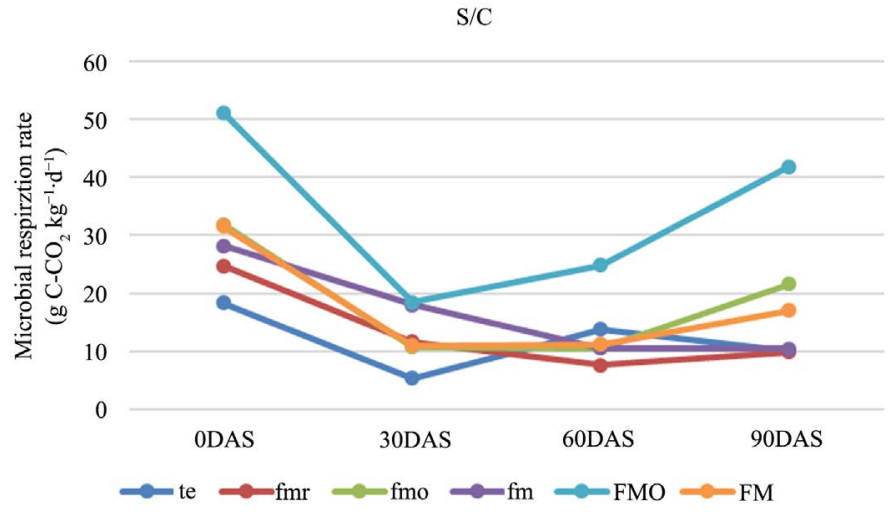

(b)

Figure 2. Microbial respiration rate of soil sampled at 0, 30, 60 and 90 days after sowing as affected by crop rotation and fertilization regimes at the Saria long-term experiment in Burkina Faso, West Africa. Each point represents an average for the three field replicates.

$41 \pm 0.3 \mu \mathrm{g} \mathrm{C}-\mathrm{CO}_{2} \mathrm{~kg}^{-1} \cdot \mathrm{d}^{-1}$ recorded at 0DAS and 90DAS respectively. The lowest respiration rates were observed with the control $22 \pm 0.3$ and $12 \pm 0.4 \mu \mathrm{g}$ $\mathrm{C}-\mathrm{CO}_{2} \mathrm{~kg}^{-1} \cdot \mathrm{d}^{-1}$.

In the $\mathrm{S} / \mathrm{C}$ rotation, similar patterns were observed as for $\mathrm{S} / \mathrm{S}$ rotation. The highest respiration rates were observed with FMO and the lowest with the control (te). At 0DAS, respiration rate varied between $51 \pm 0.7$ and $19 \pm 0.8 \mu \mathrm{g}$ $\mathrm{C}-\mathrm{CO}_{2} \mathrm{~kg}^{-1} \cdot \mathrm{d}^{-1}$; at 90DAS was $42 \pm 0.3$ and $10 \pm 0.3 \mu \mathrm{g} \mathrm{C}-\mathrm{CO}_{2} \mathrm{~kg}^{-1} \cdot \mathrm{d}^{-1}$.

\subsection{Soil Microbial Biomass C}

Microbial biomass C (MBC) was significantly different among treatment and crop rotation (Table 2 ).

$\mathrm{MBC}$ was higher in the $\mathrm{S} / \mathrm{C}$ rotation as compared to $\mathrm{S} / \mathrm{S}$ rotation in all treatment except for fmo. The highest MBC were observed with FMO treatment while the lowest one's with the control. MBC ranged from $335.5 \mu \mathrm{g} \mathrm{C} \mathrm{g}^{-1}$ soil to $54.85 \mu \mathrm{g} \mathrm{C} \mathrm{g}^{-1}$ soil and from $457.5 \mu \mathrm{g} \mathrm{C} \mathrm{g}$ soil to $86.6 \mu \mathrm{g} \mathrm{C} \mathrm{g}^{-1}$ soil with $\mathrm{S} / \mathrm{S}$ and $\mathrm{S} / \mathrm{C}$ rotation respectively.

Within the low rate of mineral fertilizer without ( $\mathrm{fm}$ ) or with organic matter addition (fmr and fmo) fmr had the highest MBC. 
Table 2. Microbial biomass ( $\mu \mathrm{g} \mathrm{C} \mathrm{g}^{-1}$ soil) following crop rotation and fertilization regimes at the Saria long-term experiment in Burkina Faso, West Africa; $(n=3)$. Treatments with the same letter within line are not statistically different at the $5 \%$ level.

\begin{tabular}{ccccccc}
\hline \multirow{2}{*}{ Rotation } & \multicolumn{7}{c}{ Treatment } \\
\cline { 2 - 7 } & te & fmr & fmo & fm & FMO & FM \\
\hline Sorghum-Sorghum & $54.8 \mathrm{a}$ & $166.5 \mathrm{~d}$ & $122.6 \mathrm{~b}$ & $111.4 \mathrm{~b}$ & $335.5 \mathrm{e}$ & $140.6 \mathrm{c}$ \\
Sorghum-cowpea & $86.6 \mathrm{a}$ & $244.0 \mathrm{c}$ & $89.1 \mathrm{a}$ & $103.7 \mathrm{~b}$ & $457.5 \mathrm{~d}$ & $237.5 \mathrm{c}$ \\
\hline
\end{tabular}

In the $\mathrm{S} / \mathrm{S}$ rotation, $\mathrm{MBC}$ content was ranked as follow: $\mathrm{FMO}>\mathrm{fmr}>\mathrm{FM}>\mathrm{fmo} \geq \mathrm{fm}>$ te and as $\mathrm{FMO}>$ $\mathrm{fmr}>\mathrm{FM}>\mathrm{fm}>\mathrm{fmo} \geq$ te in the $\mathrm{S} / \mathrm{C}$ rotation.

\subsection{Microbial Metabolic Quotient}

In general, the metabolic quotient $\left(\mathrm{qCO}_{2}\right)$ was negatively impacted by the fertilization and cowpea rotation (Table 3). For instance, with the $\mathrm{S} / \mathrm{S}$ rotation, $\mathrm{qCO}_{2}$ decreased drastically as the rate of mineral fertilization increased. The $\mathrm{qCO}_{2}$ of the control was 1.5 to 2 times that of the treatments with low mineral fertilizer (fmr, fmo and $\mathrm{fm}$ ) and 3 times that of the high rate of fertilization (FM and FMO).

Regarding the S/C rotation, the decrease in $\mathrm{qCO}_{2}$ was clearly observed with the high rate of fertilization (FM and FMO) and the restitution of sorghum straw (fmr). The $\mathrm{qCO}_{2}$ of the control was 2 times of that fmr, FM and FMO. In opposite, there was an increase of $\mathrm{qCO}_{2}$ with low rate of mineral fertilizer with (fmo) and without $(\mathrm{fm})$ manure. The $\mathrm{qCO}_{2}$ of the control was 0.6 and 0.82 times that of fmo and fm respectively.

\subsection{Soil Bacteria's Quantification}

The cowpea rotation induced higher soil bacteria with the control and fm treatments. For both rotations, soil bacteria were highest in the low rate of exclusive mineral fertilizer $(\mathrm{fm})$ and low exclusive mineral fertilization plus crop residues restitution (fmr) and lowest with low rate of mineral fertilizer plus manure application (fmo) as indicated in Table 4.

In the $S / S$ rotation, the soil bacteria count gave $91.3,6.4$ and $0.83 \times 10^{7} \mathrm{~g}^{-1}$ soil in the $\mathrm{fmr}, \mathrm{fm}$ and fmo treatment respectively. In the S/C rotation, it was 84.0, 48.10 and 1.05 respectively in the $\mathrm{fmr}, \mathrm{fm}$ and fmo treatment. In the $\mathrm{S} / \mathrm{S}$ rotation, soil bacterial with fmr were 14.3 times fm and 63.6 times the control (te). In the $\mathrm{S} / \mathrm{C}$ rotation, soil bacterial with fmr were 1.8 times fm and 12.4 times the control. In the S/S rotation, soil microbial ranked as follows: $\mathrm{fmr} \gg \mathrm{fm}>\mathrm{FMO} \geq$ te $>$ fmo while in the $S / C$ rotation, treatments were ranked as fmr $\gg \mathrm{fm} \geq$ te $>$ $\mathrm{FMO}>$ fmo $\geq \mathrm{FMO}$.

\section{Discussion}

The results of our study conducted on continuous long-term (52 years) crop rotation and application of mineral fertilizer either alone or in combination with manure or sorghum straw added strong evidence of the benefit of integrated 
Table 3. Microbial metabolic quotient $\left(\mu \mathrm{gC}-\mathrm{CO}_{2} \mu \mathrm{g}\right.$-microbial biomass-C $\left.\mathrm{kg}^{-1} \cdot \mathrm{d}^{-1}\right)$ following crop rotation and fertilization regimes at the Saria long term experiment in Burkina Faso, West Africa; $(n=3)$. Treatments with the same letter within line are not statistically different at the $5 \%$ level

\begin{tabular}{cccccccc}
\hline \multirow{2}{*}{ Rotation } & \multicolumn{7}{c}{ Treatment } \\
\cline { 2 - 7 } & te & fmr & fmo & fm & FMO & FM & p-level \\
\hline Sorghum-Sorghum & $401 \mathrm{c}$ & $266 \mathrm{~b}$ & $224 \mathrm{~b}$ & $203 \mathrm{~b}$ & $137 \mathrm{a}$ & $149 \mathrm{a}$ & $* * *$ \\
Sorghum-Cowpea & $211 \mathrm{~b}$ & $101 \mathrm{a}$ & $358 \mathrm{~d}$ & $272 \mathrm{c}$ & $112 \mathrm{a}$ & $133 \mathrm{a}$ & $* * *$ \\
\hline
\end{tabular}

Table 4. Soil bacteria count $\left(\times 10^{7} \cdot \mathrm{g}^{-1}\right.$ soil $)$ following crop rotation and treatment repeated applications at the Saria long-term experiment in Burkina Faso, West Africa; $(n=3)$. Treatments with the same letter within line are not statistically different at the $5 \%$ level.

\begin{tabular}{|c|c|c|c|c|c|c|c|}
\hline \multirow{2}{*}{ Rotation } & \multicolumn{6}{|c|}{ Treatment } & \multirow{2}{*}{ p-level } \\
\hline & te & $\mathrm{fmr}$ & fmo & $\mathrm{fm}$ & FMO & FM & \\
\hline Sorghum-Sorghum & 1.43 & 91.30 & 0.83 & 6.40 & 3.37 & 1.45 & $* * *$ \\
\hline Sorghum-Cowpea & 6.77 & 84.00 & 1.05 & 48.10 & 3.12 & 1.03 & $* * *$ \\
\hline
\end{tabular}

soil nutrients and crop management on soil biological and microbiological properties [1] [9] [14]. These results support our hypothesis that combined application of mineral fertilizer and manure result in greater microbial biomass and activity than only application of mineral fertilizer.

\subsection{Long Term Fertilization Effects on Soil Microbial Biomass and Activity}

Soil microbial respiration rate (SMR) is assessment tools for soil organic matter quality and quantity induced by crop management practices [15] which include our study crop rotation, application of organic amendments and mineral fertilizer. This implies then SMR is related to active fraction of carbon. Repeated combined application of both manures and mineral fertilizers is widely recognized as key factors to increase soil biological, chemical and physical properties [2] [14] [16] [17] which result in sustainable increase and/or maintain crop productivity [18]. In our study, there was clear indication that soil respiration rate increased with levels of manure application which is in line with several studies [19]. The observed data could be related to the greater amount of soil organic matter and nutrients. In fact, manure contains huge amount of dead and alive microorganisms, and are energy sources that stimulate higher microbial activities and respiration. As SMR is controlled by availability of C-content, a greater amount of organic matter provided more labile $\mathrm{C}$ that leads to more SMR in soils receiving organic amendment [20]. Lower SMR might indicate limited availability of C-sources and/or actives microbial biomass pool or unfavorable soil conditions for microbial activities.

A meta-analysis based on long-term trials from around the world revealed 
that mineral fertilizer application led to a $15.1 \%$ increase in the microbial as compared to unfertilized treatments [7]. In our study, the increase was much higher, up to $160 \%$ and $510 \%$ when mineral fertilizer is applied without (FM) and with manure (FMO), respectively. The magnitude of the increase observed in our study is attributed to the duration of the experiment, since it has more than 20 years [7]. Our results also revealed that application of organic amendments with mineral fertilizer increased considerably $\mathrm{MBC}$ as compared with application of mineral fertilizer alone, which is in accordance with other long-term experiments [21] [22] [23] [24] and short-term experiments [19] studies. In addition, higher crop yield reported in previous studies [25] support evidence that better crop yield generates high root biomass and exudates which combined with the readily $\mathrm{C}$-sources added through organic amendments are the key factors contributing to higher build-up of microbial biomass [22]. Straw inputs with mineral fertilizer ( $\mathrm{fmr}$ ) also increase $\mathrm{MBC}$ as compared to only mineral fertilizer $(\mathrm{fm})$ even at high rate (FM). In contrast, [26] regular and long term-term mineral fertilization led to a decrease of $\mathrm{MB}$ compared to the control and explained by the decrease in soil $\mathrm{pH}$. The lower MBC in the control unfertilized treatment was consistently reported by several studies synthetized in the review paper [7] and explained by the lower soil quality due to negative soil nutrient balance. Our results were similar to those reported by Pallo, et al. [27] and Li, et al. [28]. However, our results were up to 10 times higher than that reported by Diallo-Diagne [23] who work in a long-term tillage experiment in the same site and could be explained by the rapid carbon mineralisation following tillage and subsequently less availability of soluble carbon.

The $\mathrm{qCO}_{2}$ provides a measure of specific metabolic quotient and describes microbial stress indicators. It is interpreted as "microbial efficiency" or "carbon used efficiency" since it is a measure of the energy necessary to maintain catabolic activity i.e. microbial respiration, in relation to the energy necessary anabolic activity i.e. for synthetizing microbial biomass. The more soils are under stress, the more the $\mathrm{qCO}_{2}$ value would be higher. Some studies have shown that $\mathrm{qCO}_{2}$ varies among ecosystems, soil fertility management [29] [30]. In our study, unfertilized soil had the highest and the FMO had the lowest $\mathrm{qCO}_{2}$. Similar trends have been reported by various studies [19] [31] and imply that in unfertilized soil, microbial population lives under starvation stress. Application of manure (with mineral fertilizer) would increase nutrients content and availability resulting in favorable conditions for microbial growth and microbial diversity [8]. However, the magnitude $\mathrm{qCO}_{2}$ as highlighted by our results $(100-400 \mu \mathrm{g}$ $\mathrm{C}-\mathrm{CO}_{2} \cdot \mu \mathrm{g}$-microbial biomass-C. $\mathrm{kg}^{-1} \cdot \mathrm{d}^{-1}$ ) is five times higher than that commonly reported [9] [22] [32]. One explanation would be the long duration of the experiment (52 years) implying long soil disturbance due to agricultural practices.

Bacteria quantification showed similar number for unfertilized treatment (te) than that of fmo, FMO and FM indicating that only normal mineral fertilization with/without straw restitution increased bacteria number. It is generally expect- 
ing that bacteria numbers will be proportional to microbial biomass and respiration. In our study, the figure is opposite suggesting that in these treatments, bacteria are mostly dormant and/or constitute minor pools of soil microorganism community. Francioli, et al. [33] reported that organic fertilization increased bacterial diversity and stimulated microbial groups that are known to prefer nutrient-rich environments. In contrast, unfertilized soils exhibited distinct microbial communities enriched in oligotrophic organisms adapted to nutrient-limited environments.

\subsection{Crop Rotation Effects on Soil Microbial Biomass and Activity}

The impact of long-term crop rotations or relay crops and nutrient management on soil properties including microbial activities have been extensively studied [34], [35] [36]. The results indicated an improvement of soil fertility and subsequently an increase of cereal yield in the cereal/legume rotation as compared to continuous cereal cropping. As we hypothesized in the present study, crop rotations increased microbial biomass (by $36 \%-70 \%$ ) excepted in the fm treatment where there is no effect and fmo treatment which exhibited a decrease of $27 \%$. The overall biomass increase is consistent with many reports in tropical soil [34] [36] [37] and attributed to higher biomass roots input due to higher yield and higher enzyme activity. Lack of effect of rotation on microbial biomass has been reported by [38] and attributed to similar amount of soluble carbon used as energy sources to support microbial growth

In the present study, long-term sorghum-cowpea rotation significantly increases $\mathrm{MBC}$ and bacterial number and could be explained by the fact that microorganisms used as energy sources water-soluble carbon which originate from organic matter decomposition, microbial metabolites but also by roots exudates [39]. In the review paper, [3] reported that legume roots secrete more enzymes than cereal roots and that enzymes suppress soil fungi and limit their activity [39]. Hence, since we did not quantify fungi, we could speculate that continuous sorghum cropping would favor fungi pool and detrimental for bacteria pool while the reverse would be observed for sorghum-cowpea rotation. This assertion is supported by Yusuf, et al. [34] who report that continuous maize cultivation may favor the establishment and maintenance of fungi community in comparison with legume-maize or fallow-maize rotation in an Alfisol in Nigeria.

\section{Conclusion}

We used a long-term experiment to assess the effect of crop rotation and nutrient management practices on soil microbial activities. The results indicated that sorghum/cowpea rotation significantly increases soil microbial biomass and bacterial number as compared to continuous sorghum cropping. Repeated application of high levels of manure and mineral fertilizer increased carbon mineralization, microbial biomass, and efficient use of carbon. Hence, combined application of manure and mineral fertilizer with crop rotation is the best management practice to improve in a sustainable way microbial activity in tropical soil. 


\section{Acknowledgements}

The authors are grateful to the "Laboratoire Sol-Eau-Plante" of the "Institut de l'Environnement et de Recherches Agricoles (INERA)", Burkina Faso, for supporting this research. We are grateful to the field technicians Coulibaly Dofinita and Sanon Martin for their assistance during the fieldwork, and to Moyenga Momini, Ramdé Martin and Kaboré Jean-Paul for the lab analysis.

\section{Conflicts of Interest}

The authors declare no conflicts of interest regarding the publication of this paper.

\section{References}

[1] Traore, M., Lompo, F., Thio, B., Ouattara, B., Ouattara, K. and Sedogo, P.M. (2012) Influence de la rotation culturale avec apport de matières organiques exogènes et d'une fertilisation minérale sur les nématodes phytoparasites en culture du sorgho au Centre Ouest du Burkina Faso. International Journal of Biological and Chemical Sciences, 6, 628-640. https://doi.org/10.4314/ijbcs.v6i2.7

[2] Ouandaogo, N., Ouattara, B., Pouya, M.B., Gnankambary, Z., Nacro, H.B. and Sedogo, P.M. (2016) Effets des fumures organo-minérales et des rotations culturales sur la qualité des sols. International Journal of Biological and Chemical Sciences, 10, 904-918. https://doi.org/10.4314/ijbcs.v10i2.37

[3] Franke, A.C., Van den Brand, G.J., Vanlauwe, B. and Giller, K.E. (2018) Sustainable Intensification through Rotations with Grain Legumes in Sub-Saharan Africa: A Review. Agriculture, Ecosystems and Environment, 261, 172-185. https://doi.org/10.1016/j.agee.2017.09.029

[4] Venter, Z.S., Jacobs, K. and Hawkins, H.-J. (2016) The Impact of Crop Rotation on Soil Microbial Diversity: A Meta-Analysis. Pedobiologia, 59, 215-223.

https://doi.org/10.1016/j.pedobi.2016.04.001

[5] Sanchez, P.A., Shepherd, K.D., Soule, M.J., Place, F.M, Buresh, R.J., Izac, A.M.N., Mokwunye, A.U., Kwesiga, F.R., Ndiritu, C.G. and Woomer, P.L. (1997) Soil Fertility Replenishment in Africa: An Investment in Natural Resource Capital. In: Buresh, R., Sanchez, P.A. and Calhoun, F., Eds., Replenishing Soil Fertility in Africa, Vol. 51, Soil Science Society of America, American Society of Agronomy, Madison, 1-46. https://doi.org/10.2136/sssaspecpub51.c1

[6] Gnankambary, Z., Stedt, U., Nyberg, G., Hien, V. and Malmer, A. (2008) Nitrogen and Phosphorus Limitation of Soil Microbial Respiration in Two Tropical Agroforestry Parklands in the South-Sudanese Zone of Burkina Faso: The Effects of Tree Canopy and Fertilization. Soil Biology and Biochemistry, 40, 350-359. https://doi.org/10.1016/j.soilbio.2007.08.015

[7] Geisseler, D. and Scow, K.M. (2014) Long-Term Effects of Mineral Fertilizers on Soil Microorganisms-A Review. Soil Biology and Biochemistry, 75, 54-63. https://doi.org/10.1016/j.soilbio.2014.03.023

[8] Traoré, O.Y.A., Kiba, D. I., Arnold, M.C., Fliessbach, A., Oberholzer, H. R., Nacro, H.B., Lompo, F., Oberson, A., Frossard E. and Bunemann, E.K. (2016) Fertilization Practices Alter Microbial Nutrient Limitations after Alleviation of Carbon Limitation in a Ferric Acrisol. Biology and Fertility of Soils, 52, 177-189. https://doi.org/10.1007/s00374-015-1061-9 
[9] Choudharya, M., Meenaa, V.S., Pandaya, S.C., Mondala, T., Yadava, R.P., Mishraa, P.K., Bishta, J.K. and Pattanayaka, A. (2021) Long-Term Effects of Organic Manure and Inorganic Fertilization on Biological Soil Quality Indicators of Soybean-Wheat Rotation in the Indian Mid-Himalaya. Applied Soil Ecology, 157, Article ID: 103754. https://doi.org/10.1016/j.apsoil.2020.103754

[10] Coleman, D.C., Anderson, R.V., Cole, C.V., Elliott, E.T., Woods L. and Campion, M.K. (1978) Trophic Interactions in Soils as They Affect Energy and Nutrient Dynamics. IV: Flows of Metabolic and Biomass Carbon. Microbial Ecology, 4, 373-380. https://doi.org/10.1007/BF02013280

[11] Dommergues, Y. (1960) La notion de coefficient de minéralisation du carbone dans les sols. Agronomie Tropicale, 15, 54-60.

[12] Jenkinson, D.S. and Powlson, D.S. (1976) The Effects of Biocidal Treatments on Metabolism in Soil. I. Fumigation with Chloroform. Soil Biology and Biochemistry, 8, 167-177. https://doi.org/10.1016/0038-0717(76)90001-8

[13] Anderson, J.P.E. and Domsch, K.H. (1978) A Physiological Method for the Quantitative Measurement of Microbial Biomass in Soils. Soil Biology and Biochemistry, 10, 215-221. https://doi.org/10.1016/0038-0717(78)90099-8

[14] Vanlauwe, B. and Giller, K.E. (2006) Popular Myths around Soil Fertility Management in Sub-Saharan Africa. Agriculture, Ecosystems and Environment, 116, 34-46. https://doi.org/10.1016/j.agee.2006.03.016

[15] Gregorich, E.G., Carter, M.R., Angers, D.A., Monreal, C.M. and Ellert, B.H. (1994) Towards a Minimum Data Set to Assess Soil Organic Matter Quality in Agricultural Soils. Canadian Journal of Soil Science, 74, 367-385. https://doi.org/10.4141/cjss94-051

[16] Gnankambary, Z. (2007) Compost and Fertilizer Mineralization Effects on Soil and Harvest in Parkland Agroforestry Systems in the South-Sudanese Zone of Burkina Faso. PhD Thesis, Swedish University of Agricultural Sciences, Umeå, 129.

[17] Soma, D.M., Kiba, D.I, Gnankambary, Z., Ewusi-Mensah, N., Sanou, M., Nacro, H.B., Lompo, F., Sedogo, P.M. and Abaidoo, R.C. (2017) Effectiveness of Combined Application of Kodjari Phosphate Rock, Water Soluble Phosphorus Fertilizer and Manure in a Ferric Lixisol in the Centre West of Burkina Faso. Archives of Agronomy and Soil Science, 64. 384-397. https://doi.org/10.1080/03650340.2017.1353216

[18] Bationo, A. Waswa, B., Kihara, J., Adolwa, I., Vanlauwe, B. and Koala, S. (2012) Lessons Learned from Long-Term Soil Fertility Management Experiments in Africa. Springer, Dordrecht. https://doi.org/10.1007/978-94-007-2938-4

[19] Ma, Q., Wen, Y., Wang, D., Sun, X., Hill, P.M., Macdonald, A., Chadwick, D.R., Wu, L. and Jones, D.L. (2020) Farmyard Manure Applications Stimulate Soil Carbon and Nitrogen Cycling by Boosting Microbial Biomass Rather than Changing Its Community Composition. Soil Biology and Biochemistry, 144, Article ID: 107760. https://doi.org/10.1016/j.soilbio.2020.107760

[20] Min, D.H., Islam, K.R., Vough, L.R. and Weil, R.R. (2003) Dairy Manure Effects on Soil Quality Properties and Carbon Sequestration in Alfalfa-Orchard Grass Systems. Communications in Soil Science and Plant Analysis, 34, 781-799. https://doi.org/10.1081/CSS-120018975

[21] Heinze, S., Raupp, J. and Joergensen, R.G. (2010) Effects of Fertilizer and Spatial Heterogeneity in Soil $\mathrm{pH}$ on Microbial Biomass Indices in a Long-Term Field Trial of Organic Agriculture. Plant and Soil, 328, 203-215. https://doi.org/10.1007/s11104-009-0102-2 
[22] Liu, E., Yan, C., Mei, X., He, W., Bing, S.H., Ding, L., Liu, Q., Liu, S. and Fan, T. (2010) Long-Term Effect of Chemical Fertilizer, Straw, and Manure on Soil Chemical and Biological Properties in Northwest China. Geoderma, 158, 173-180. https://doi.org/10.1016/j.geoderma.2010.04.029

[23] Diallo-Diagne, N.H, Assigbetse, K. S. Sall, Masse, D. Bonzi, M. Ndoye I. and Chotte, J.L. (2016) Response of Soil Microbial Properties to Long-Term Application of Organic and Inorganic Amendments in a Tropical Soil (Saria, Burkina Faso). Open Journal of Soil Science, 6, 21-33. https://doi.org/10.4236/ojss.2016.62003

[24] Chen, D., Yuan, L., Liu, Y., Ji, J. and Hou, H. (2017) Long-Term Application of Manures Plus Chemical Fertilizers Sustained High Rice Yield and Improved Soil Chemical and Bacterial Properties. European Journal of Agronomy, 90, 34-42. https://doi.org/10.1016/j.eja.2017.07.007

[25] Soma, D.M. Kiba, D.I., Ewusi-Mensah, N., Gnankambary, Z., Lompo, F., Sedogo M.P. and Abaidoo, R.C. (2018) Changes in Sorghum Production, Soil P Forms and P Use Efficiency Following Long-Term Application of Manure, Compost and Straw in a Ferric Lixisol. Acta Agriculturae Scandinavica, Section B-Soil \& Plant Science, 68, 401-411. https://doi.org/10.1080/09064710.2017.1414871

[26] Černý, J., Balík, J., Kulhánek, M. and Nedvěd, V. (2008) The Changes in Microbial Biomass $\mathrm{C}$ and $\mathrm{N}$ in Long-Term Field Experiments. Plant, Soil and Environment, 54, 212-218. https://doi.org/10.17221/393-PSE

[27] Pallo, F.J.P, Sawadogo, N., Sawadogo, L., Sedogo, M.P. and Assa, A. (2008) Statut de la matière organique des sols dans la zone sud-soudanienne au Burkina Faso. Biotechnologie, Agronomie, Société et Environnement, 12, 291-301.

[28] Li, C.-X., Ma, S.-C., Shao, Y., Ma, S.-T. and Zhang, L.-I. (2018) Effects of Long-Term Organic Fertilization on Soil Microbiologic Characteristics, Yield and Sustainable Production of Winter Wheat. Journal of Integrative Agriculture, 17, 210-219. https://doi.org/10.1016/S2095-3119(17)61740-4

[29] Jones, D.L., Hill, P.W., Smith, A.R., Farrell, M., Ge, T., Banning, N.C. and Murphy, D.V. (2018) Role of Substrate Supply on Microbial Carbon Use Efficiency and Its Role in Interpreting Soil Microbial Community-Level Physiological Profiles (CLPP). Soil Biology and Biochemistry, 123, 1-6. https://doi.org/10.1016/j.soilbio.2018.04.014

[30] Zheng, Q., Hu, Y., Zhang, S., Noll, L., Beockle, T., Richter, A. and Wanek, W. (2019) Growth Explains Microbial Carbon Use Efficiency across Soils Differing in Land Use and Geology. Soil Biology and Biochemistry, 128, 45-55.

https://doi.org/10.1016/j.soilbio.2018.10.006

[31] Liu, Y.-R., Delgado-Baquerizo, M., Wang, J.-T., Hu, H.-W., Yang, Z. and He, J.-Z. (2018) New Insights into the Role of Microbial Community Composition in Driving Soil Respiration Rates. Soil Biology and Biochemistry, 118, 35-41. https://doi.org/10.1016/j.soilbio.2017.12.003

[32] Ge, G., Li, Z., Fan, F., Chu, G., Hou, Z. and Liang, Y. (2010) Soil Biological Activity and Their Seasonal Variations in Response to Long-Term Application of Organic and Inorganic Fertilizers. Plant and Soil, 326, Article No. 31. https://doi.org/10.1007/s11104-009-0186-8

[33] Francioli, D., Schulz, E., Lentendu, G., Wubet, T., Buscot, F. and Reitz, T. (2016) Mineral vs. Organic Amendments: Microbial Community Structure, Activity and Abundance of Agriculturally Relevant Microbes Are Driven by Long-Term Fertilization Strategies. Frontiers in Microbiology, 7, Article No. 1446. https://doi.org/10.3389/fmicb.2016.01446 
[34] Yusuf, A.A., Iwuafor, E.N.O., Abaidoo, R.C., Olufajo, O.O. and Sanginga, N. (2009) Grain Legume Rotation Benefit to Maize in the Northern Guinea Savanna of Nigeria: Fixed Nitrogen versus Other Rotation Effects. Nutrient Cycling in Agroecosystems, 84, 129-139. https://doi.org/10.1007/s10705-008-9232-9

[35] Ouda, S., Zohry, A. and Noreldin, T. (2018) Crop Rotation Maintains Soil Sustainability. In: Ouda, S., Zohry, A.E.H. and Noreldin, T., Eds., Crop Rotation: An Approach to Secure Future Food, Springer, Cham, 55-76.

https://doi.org/10.1007/978-3-030-05351-2_4

[36] Borase, D.N., Nath, C.P., Hazra, K.K., Senthilkumar, M., Singh, S.S., Praharaj, C.S., Singha, U. and Kumar, N. (2020) Long-Term Impact of Diversified Crop Rotations and Nutrient Management Practices on Soil Microbial Functions and Soil Enzymes Activity. Ecological Indicators, 114, Article ID: 106322.

https://doi.org/10.1016/j.ecolind.2020.106322

[37] McDaniel, M.D. and Grandy, A.S (2016) Soil Microbial Biomass and Function Are Altered by 12 Years of Crop Rotation. SOIL, 2, 583-599.

https://doi.org/10.5194/soil-2-583-2016

[38] Balota, E.L., Colozzi-Filho, A., Andrade, D.S. and Dick, R.P. (2003) Microbial Biomass in Soils under Different Tillage and Crop Rotation Systems. Biology and Fertility of Soil, 38, 15-20. https://doi.org/10.1007/s00374-003-0590-9

[39] Sylvia, D.M., Fuhrmann, J.J., Hartel, P.G. and Zuberer, D.A. (2005) Principles and Applications of Soil Microbiology. 2nd Edition, Pearson Prentice Hall Inc., Upper Saddle River, $640 \mathrm{p}$. 